\title{
Jean Cavailles: life and death. - Georges Canguilhem
}

Camille Akmut (trans.)

2019 


\section{INAUGURATION OF THE JEAN CAVAILLES AUDITORIUM AT THE NEW FACULTY OF LETTERS OF STRASBOURG}

May 9th, 1967 
Dear Madams and Mademoiselles,

Dear Sirs, Students:

The life, career and destiny of Jean Cavailles can be presented in few words. Born in 1903, "dad military", Protestant, from a background in science originally, student at the Ecole Normale Superieure - class of 1923, B.S. in mathematics, Rockerfeller grant recipient in Germany, a teacher's teacher [agrege-repetiteur], again at the Ecole Normale Superieure, high-school teacher in Amiens, doctor of letters 1938, AssistantProfessor of Logic and Philosophy at the Faculty of Letters of Strasbourg;

enlisted in 1939 as officer in the Corps Franc, then as cipher / encryption officer [Officier du Chiffre], prisoner of the Germans - June of 1940, escaped, and returned to the University of Strasbourg, now forcefully relocated in Clermont-Ferrand, where he was appointed substitute Professor of Logic in 1941, co-founder of the Resistance movement "Liberation Sud", founder of the "Cohors" network, arrested by the French police in August of 1942, interned in Montpellier then Saint-Paul d'Eyjeaux, he escaped again in December 1942, and was arrested again by German counter-intelligence [Gestapo?] in August 1943, repudiated by the Government of Vichy, shot by the Germans and buried in the Citadel of Arras in February 1944, Companion of the Liberation [honorary title] and Knight of the Legion of Honour in a posthumous capacity.

In Strasbourg, in that very same Faculty where he had been professor, I now find myself speaking of Jean Cavailles for the first time.

In its second issue for the year 1945, the Bulletin of the Faculty of Letters of Strasbourg has reproduced a speech by Henry Cartan - then professor here, in your Faculty of Sciences, and mine - given at the Sorbonne on the occasion of a commemorative ceremony held by the University of Paris and the various Resistance organizations. 1945-1967. Almost a quarter of a century ago. Times have changed, as have locations...

But, how exactly do we talk - through which appropriate means - of a philosopher of the Resistance, 
shot by the Germans in 1944? In the same city, robed, as if in a wish or an anticipation, in European unity? Strasbourg. Do we let old times spoil current ones? And, on the other hand, can we allow them to make us forget? A thick haze over the city... A fiery flame like coming from a firing squad...

I thought hard, and decided to leave nothing aside, of the man and his military actions. I intend to erase nothing where the effects and the facts are concerned, of that epoch. As it remains fact that his choices had reasons, and that they too created facts, facts that history may lend different colors, but it cannot do away with them.

It has become fashion for students to complain of not having the professors they deserve; just as the latter feel they don't have the students to dignify their qualities. An effect of great numbers.

But, put yourself now in the stead of your predecessors, your elders : the handful of Strasbourg students - among whom one of your teachers - who became in 1938 the first students of Jean Cavailles. Now picture a young professor, of slightly bad posture (a back not straight), but a resolute walking style, a pensive and stubborn forehead, a behavior secretive and cordial, with no compromised or easy thoughts, but great, vulnerable sensibility.

The man is appealing and derisive, playful like a child and solitary, he lives in the realm of rigorous concepts, but also music and poetry. He remains deeply attached to a family whose culture values moral elevation and genuine, sincere faith.

Thus imagine him arriving in Strasbourg, in front of his students, at the same time when Bourbaki had just begun to unveil a new mode of mathematical thought to the world, with the ambition - his bounded to his own country - to turn the philosophy of mathematics into a strict discipline, with a rigor analogous to that of which was its object; no more wish-washy approximations.

He knows exactly where to look, and where inside philosophical speculation a place awaits - like a destiny.

Cavailles never really had felt that, by doing what he was doing, he had become master of his own choices, 
no more than by moving forward he was free to go backwards. As he was working on his thesis, to his sister he wrote :

"I assure you that, if I am doing this thesis, it is neither due to ambition - I have never cared less for a career - nor is it that I am foolish enough to believe it will be useful to philosophy, but having undertaken it now, it moves: even a thesis in philosophy has some essence of its own, to which we may participate but always with the feeling of sin were this collaboration to be interrupted."

One day was sure to come, where - now having to turn to another task of similar essence - he would feel compelled to participate - down to the bottom of death.

Don't forget that this professor, newly arrived in Strasbourg, was most familiar with Germans, and Germany - through first-hand experiences. He had lived there, first as the recipient of a scholarship, he returned multiple times, he worked at universities, in Berlin, Hamburg, Gottingen, Munich and Freiburg, he associated with youth movements.

In the 1930's, most often it was from Germany that he was able to observe French politics, interior and exterior. In Hamburg, the so-called 'free city' of Hamburg, he saw socialists unify "in the same homage, Bismarck, founder of the first Empire, and Ebert, conservative of the second." In Munich, in 1931, he heard a demagogue in boots (proclaim loud and proud in beer houses)...; in 1934, he read Mein Kampf; in 1936, in Altona [near Hamburg], he met opponents of the Hitler regime who were only able to escape concentration camps narrowly - but for how long?

In 1931, in Freiburg, he visited Husserl, an aged man, rendered bitter by Heidegger's fame.

Let's be clear : when Cavailles was walking in Strasbourg streets, and he read the local newspapers, a great many things, acts and facts took on a meaning for him - the meaning they should have had, or that we will one day surely have to assign to them. 
This son of an officer, turned professor, now finds himself Lieutenant in the Corps Franc, in charge of a colonial infantry regiment - just before Forbach. His actions, then, won him his first citation : for bold and successful action. The War moving towards uncertainty, caught in anticipations or expectations, he became a cipher officer for the Ministry of War. Transferred in May 1940 to the military headquarters [etatmajor] of the 4th colonial division, he then became the victim of the rapid undoing of the French military system and was captured by the Germans.

Imagine now Cavailles prisoner: A German officer, in charge of interrogation, asks him, so as to reassert the great degradation of his country : "Well, how does it feel to have fallen faster than Poland?"; and meanwhile an old peasant from Beaupaume says, in collective damnation : "At least in that other War, we never surrendered."

Cavailles escapes, and through Belgium reaches Lille. A daredevil's bet? a refusal to accept facts, as they are, after all, only the facts? or was it again, this feeling, this feeling so strong and compelling of having to see a task through? An academic left with no choice goes to a university as a priest goes running back to a covenant. But, this time imagine Cavailles having to hear from some high-up-there gentleman from the University of Lille : "But, you're a deserter!" - as if a resigned acceptance of captivity was some form of military duty, or civic, or moral.

Cavailles might have felt hurt only if this assimilation of evasion with desertion had uncovered a larger truth, which had no hold on him. He had not escaped merely to avoid a long captivity, only to then go back to a peaceful and pleasant life as a scholar... and wear the bathrobe and slippers of the writer... to "preserve his intellect for the glory of his nation" - as some did or might have thought.

Whatever the reasons of our military defeat in 1940, and whatever judgments may have been passed on it since, it remains that occupation was humiliation in the short term, slavery in the long.

One had to believe themselves expert in the ways and ends of Providence, to see here a promise of moral buy-back; the power of belief had to stretch far out 
and back for anyone to see in these events an opportunity for political redemption or social revolution. And, if all Germans had not been Nazis, Nazism on the other hand was not a philosophy [i.e. an abstraction of the mind, only]. Following his reading of Mein Kamp in 1934, Cavailles wrote :

"It's characteristic of these people that, not even being in power yet - or retreating as Napoleon - their leader should have felt the need to give birth to 600 dense pages of complete pseudo-philosophy..."

As for myself, I prefer to say anti-philosophy [counterphilosophy]: at the origin of this system was an improvised sum, whose purpose was mass conditioning, was the hatred and absolute refusal of universal. This being said, it should surprise no one that Cavailles drew no other conclusion from this than an even greater will and willingness to fight.

Having returned to his Faculty, now in ClermontFerrand, the so-called "free zone", Cavailles resumed his teaching and started to build a network with the goal of creating an organization of resistance. I'm unable to give back in all details the entirety of his activities then:

With Jean Rochon, editorial secretary [secretaire de redaction] of the newspaper La Montagne, who would later die in deportation, Cavailles had tried to find the means for a clandestine publication.

With Emmanuel d'Astier de la Vigerie, he founded the movement called "Liberation Sud" [Southern Liberation]. I saw Cavailles and d'Astier writing the manifesto for it in one of the inner courts of the Faculty of letters [of the University of Clermont-Ferrand]. Strasbourg remained constantly near Cavaille's thoughts.

It was to him that a poster - circulated through underground networks - was delivered, a poster affixed to one of your walls, that showed a Germanic broom pushing into a trash bin an assortment of Mariane bust, Gallic rooster, and Basque Beret. The inscription on it read : "Out with the French riff-raff!". This was one of the first illustrations found in the clandestine French press (based on an original from Toulouse).

But, one would be very mistaken about the personality and nature of Cavailles if one were to think that 
this is where things would stop, that writing manifests, and creating a movement, and animating opinions would be the end.

Let's be clear: the end of this enterprise was direct action, an active, armed resistance. And, hence the creation, by him, of an armed organization called "Cohors".

I'll skip a bit now. In your mind, picture now Cavailles overseeing and ordering various operations of sabotage and information gathering. Imagine only now this philosopher, both thoughtful and resolute, executing acts of terrorism himself! And on the beaches of Languedoc, where he was arrested after a failed attempt to reach England - prisoner, this time, of the French, and imagine him again thinking only of escape, and succeeding yet again.

In London, where he arrived in February of 1943, he spent 2 months. From there he returned in charge of even more dangerous operations than in the past. At this point he ceases all supervising functions in Resistance committees, and dedicates himself entirely to action. This is also the time when he will witness his clandestine network severely weakened by multiple arrests, left disorganized.

One last time use your imagination, and picture one of your young professors, in blue workers' clothes, introducing himself at the submarine base of the Kriegsmarine [German "navy"] in Lorrient. Behind the mask of a responsible workman named "Carriere"... Cavailles! And, anyone thinking he wasn't fearing for his life then - you're out of your minds. Like that false buddy of his, who claimed after the War that the Resistance had been "vacations" for Cavailles. [If vacations, permanent ones.....

I met Cavailles one last time in May of 1943, in a restaurant of the Rue de Sevres, where we were joined by his adjunct Jean Gosset, another student of the Ecole Normale, another graduated philosopher, another one who would die in deportation - I can guarantee that he was not on holidays, if anything but an extension before his arrest.

A few weeks later, he was arrested again, but this time torture and death.

Cavailles was executed (by firing squad) at the be- 
ginning of 1944, in Arras, after being condemned to death by a military tribunal. For those who discovered him there, inside a mass grave, somewhere in the corner of this Citadel, he was the Unknown $n^{\circ} 5$.

This is where imagination ends.

I often thought that there couldn't have been a more moving epigraph, even if sought out, for a philosopher mathematician : five, the Pythagoric sum of the first even and odd numbers; and the unknown, this limit of our thought, of which philosophy has made much, whereas mathematics has reduced to a simple matter of calculation the same.

There were many ways to be worthy [upright] and courageous under the Occupation - many of which were the products of men and women of simple backgrounds, their acts only known to them, their authors. What distinguishes Cavailles was that he had seen through his task at a national level, yet devoid of any political ambitions - this is not to say without political consciousness.

We must stop imagining now, to understand what his actions owed to his philosophy. 


\section{Translator's notes}

Inauguration lecture delivered to the students of the University of Strasbourg, hence the constant references to it ("your walls", etc.).

The text is roughly organized in 1 . life 2 . philosophy...

Canguilhem draws parallels between Cavailles' thesis, and his activities in the Resistance.

(Was the letter to Gabrielle?)

- Madams and Mademoiselles :

Corresponding to Mrs. and Ms..

- Corps Franc :

See Free Corps, Freikorps...

- Officier du Chiffre

Chiffre meaning : number.

- Strasbourg, Clermont-Ferrand :

The former is located towards the North-East of France, next to the border with Germany, the other further to the South.

- Compagnion de la Liberation, Chevalier de la Legion d'Honneur

- Bulletin de la Faculte des Lettres de Strasbourg

- Altona :

Now district of Hamburg, previously city.

- Forbach :

About $10 \mathrm{~km}$ away from the German border, perhaps more, perhaps less. 